\title{
Infecciones virales y bacterianas en Gastroenterología
}

\author{
Viral and Bacterial Infections in Gastroenterology
}

En este segundo número de la revista Gastroenterología Latinoamericana, destacamos el artículo de revisión sobre hepatitis B crónica, de los Dres. Ignacio Gran y Alejandro Soza. En la misma sección los Dres. Javier Chahuán A., Margarita Pizarro R., Alejandro Villalón F., Luis A. Díaz P. y Arnoldo Riquelme P. nos presentan una visión actualizada respecto a los métodos de diagnóstico para la detección de la infección por Helicobacter pylori, incluyendo pros y contras del uso de métodos invasivos y no invasivos, así como la utilidad de cultivos y técnicas de reacción de polimerasa en cadena (PCR) para detección de la bacteria, así como de la sensibilidad a antibióticos.

En la sección de casos clínicos, se incluye un reporte de caso de Páncreas ectópico, que constituye un hallazgo accidental en gastroenterología durante la realización de endoscopias digestivas altas y que todo especialista debe saber reconocer. Los Dres. Diego Vallejo D., Diego Rueda R., Cristóbal Eggers de J., y Carlos Rueda Q, incluyen una revisión de la literatura. En la misma sección, los Dres. Nicolás Vargas P., Sergio Illanes D., Lorna Galleguillos G. y Felipe Moscoso J. nos presentan un caso de hepatotoxicidad severa inducida por sertralina. Este reporte es relevante por la frecuencia de prescripción de psicofármacos, en particular de antidepresivos de la familia de los inhibidores de recaptura de serotonina, y por la creciente preocupación de gastroenterólogos y hepatólogos por daño hepático inducido por drogas. Finalmente, los Dres. Andrés Labra W., Giancarlo Schiappacasse F., Israel Díaz A., Isabel Adlerstein L., Alex Navarro R. y Daniel Carvajal H. nos presentan un caso de gastroenteritis eosinofílica, en que se realiza una revisión de aspectos clínicos e imagenológicos de esta entidad poco frecuente.

En la sección de Medicina basada en la evidencia en Gastroenterología las Dras. Sofía Kutscher C, María Josefina Lorenzoni G., nos presentan el análisis crítico de un artículo sobre un régimen basado en vonoprazan, que es más efectivo que el basado en inhibidores de la bomba de protones, como primera línea en la erradicación de Helicobacter pylori. Este estudio es de alto interés por el uso de este fármaco en el futuro, con un bloqueo más efectivo de la secreción ácida, mejorando las tasas de erradicación, y que promete ser un nuevo estándar dentro de los esquemas de erradicación en el futuro.

Para finalizar, en estos tiempos de pandemia por COVID-19, los Dres. Mauricio González M., Juan Pablo Ortega R., Gustavo Walsen A., Blanca Norero M. y Alex Arenas A., nos entregan sentido homenaje en memoria del Dr. José René Sánchez, destacado miembro de la Sociedad Chilena de Gastroenterología que dedicó su vida al cuidado de los pacientes más necesitados en el Hospital Dr. Sótero del Río, y que nos dejó como legado su abnegación y compromiso público. El Dr. Sánchez nos deja, convirtiéndose en el primer médico que fallece a consecuencia de la infección por SARS-CoV-2. Nuestro más sentido pésame, en nombre de nuestro equipo editorial y el directorio de la Sociedad Chilena de Gastroenterología (SChGE), a la familia de este destacado miembro de la SChGE, que se complementa con el sentido mensaje del directorio, que se encuentra disponible en la sección de cartas al editor.

Dr. Arnoldo Riquelme P. Editor Revista Gastroenterología Latinoamericana 


\section{Cartas al Editor}

\section{In memoriam}

La pandemia COVID-19 ha afectado a todos, pero ha sido especialmente dura para nuestra Sociedad pues uno de nuestros socios, el Dr. René Sánchez Bascuñán, fue la primera víctima en Chile de profesión médico. Desde SChGE le rendimos un muy sincero homenaje para un profesional tan destacado y querido por todos quienes trabajamos con él mediante la siguiente carta fue publicada en los medios de comunicación nacionales.

\section{Adiós al Dr. René Sánchez}

Ante la dolorosa partida del Dr. José René Sánchez Bascuñán desde la Sociedad Chilena de Gastroenterología (SChGE) queremos expresar nuestro sentimiento de pesar a su familia, a los colegas de su Hospital Dr. Sótero del Río, al equipo de los servicios de Medicina y de Gastroenterología y a todo el personal de la salud que trabajó con él.

Todos sabemos que nuestras profesiones de servicio implican sacrificios y riesgos, que en casos excepcionales puede significar dar la vida para preservar la de los demás. El doctor Sánchez encarnó esto en todas sus formas.

Su interés por la academia y la docencia hizo que siempre fuera miembro destacado de nuestra SChGE. Todo quien lo conoció destacó en él su afecto y sencillez, profesionalismo incansable y preocupación por los pacientes, cualidades que lo caracterizaban. Siempre se le escuchaba decir: "voy a darme una vueltita por si quedó algo pendiente" y más de alguna vez o casi siempre, regresaba al servicio de endoscopia con algún paciente, muchas veces "haciendo de camillero" de ser necesario, para realizar algún procedimiento.

Su calidad humana la demostraba en cada detalle. Por ejemplo, para todas las Navidades René se preocupaba de regalarle "un chocolatito" a cada persona con la que había trabajado durante el año; guardando el detalle de que cada presente iba con el nombre del destinatario escrito por él. Y si alguien del equipo enfermaba le confiaban su salud al Dr. Sánchez, quien lo acogía y atendía solucionando la dolencia.

Dado su gran amor por la profesión, no pudo dejar de ir al hospital, a "su" hospital. Podría haberse ido a su casa cuando comenzó la pandemia, pero no dejó de atender pacientes, pues en esas circunstancias era cuando más lo necesitaban. El juramento de Hipócrates dice: "desempeñaré mi arte con conciencia y dignidad". René ha pasado a ser testimonio de esto con su entrega y máximo sacrificio.

Colega y amigo, descansa en paz.

Directorio Sociedad Chilena de Gastroenterología Mayo de 2020 